\title{
MINIMUM MISCIBILITY PRESSURE COMPUTATION IN EOR BY FLARE GAS FLOODING
}

\author{
Tjokorde Walmiki Samadhi ${ }^{*}$, Utjok W.R. Siagian ${ }^{2}$ and Angga P. Budiono ${ }^{1}$ \\ ${ }^{1}$ Chemical Engineering Program, Faculty of Industrial Technology, \\ ${ }^{2}$ Petroleum Engineering Program, Faculty of Mining and Petroleum Engineering, \\ Institut Teknologi Bandung \\ Jalan Ganesha 10 Bandung 40132, Indonesia \\ Email: twsamadhi@che.itb.ac.id
}

\begin{abstract}
The technical feasibility of using flare gas in the miscible gas flooding enhanced oil recovery (MGF-EOR) is evaluated by comparing the minimum miscibility pressure (MMP) obtained using flare gas to the MMP obtained in the conventional $\mathrm{CO}_{2}$ flooding. The MMP is estimated by the multiple mixing cell calculation method with the Peng-Robinson equation of state using a binary $\mathrm{nC}_{5} \mathrm{H}_{12}-\mathrm{nC}_{16} \mathrm{H}_{34}$ mixture at a $43 \%: 57 \%$ molar ratio as a model oil. At a temperature of $323.15 \mathrm{~K}$, the MMP in $\mathrm{CO}_{2}$ injection is estimated at $9.78 \mathrm{MPa}$. The MMP obtained when a flare gas consisting of $\mathrm{CH}_{4}$ and $\mathrm{C}_{2} \mathrm{H}_{6}$ at a molar ratio of $91 \%: 9 \%$ is used as the injection gas is predicted to be 3.66 times higher than the $\mathrm{CO}_{2}$ injection case. The complete gas-oil miscibility in $\mathrm{CO}_{2}$ injection occurs via the vaporizing gas drive mechanism, while flare gas injection shifts the miscibility development mechanism to the combined vaporizing / condensing gas drive. Impact of variations in the composition of the flare gas on MMP needs to be further explored to confirm the feasibility of flare gas injection in MGF-EOR processes.
\end{abstract}

Keywords: flare gas, MMP, miscible gas flooding, EOR

\begin{abstract}
Abstrak
Konsep penggunaan flare gas untuk proses enhanced oil recovery dengan injeksi gas terlarut (miscible gas flooding enhanced oil recovery atau MGF-EOR) digagaskan untuk mengurangi emisi gas rumah kaca dari fasilitas produksi migas, dengan sekaligus meningkatkan produksi minyak. Kelayakan teknis injeksi flare gas dievaluasi dengan memperbandingkan tekanan pelarutan minimum (minimum miscibility pressure atau MMP) untuk injeksi flare gas dengan MMP pada proses MGF-EOR konvensional menggunakan injeksi $\mathrm{CO}_{2}$. MMP diperkirakan melalui komputasi dengan metode sel pencampur majemuk dengan persamaan keadaan Peng-Robinson, pada campuran biner $\mathrm{nC}_{5} \mathrm{H}_{12}-\mathrm{nC}_{16} \mathrm{H}_{34}$ dengan nisbah molar 43\%:57\% sebagai model minyak. Pada temperatur $323.15 \mathrm{~K}$, estimasi MMP yang diperoleh dengan injeksi $\mathrm{CO}_{2}$ adalah $9.78 \mathrm{MPa}$. Nilai MMP yang diperkirakan pada injeksi flare gas yang berupa campuran $\mathrm{CH}_{4}-\mathrm{C}_{2} \mathrm{H}_{6}$ pada nisbah molar 91\%:9\% sangat tinggi, yakni sebesar 3.66 kali nilai yang diperoleh pada kasus injeksi $\mathrm{CO}_{2}$. Pelarutan sempurna gas-minyak dalam injeksi $\mathrm{CO}_{2}$ terbentuk melalui mekanisme dorongan gas menguap (vaporizing gas drive), sementara pelarutan pada injeksi flare gas terbentuk melaui mekanisme kombinasi dorongan gas menguap dan mengembun (vaporizing / condensing gas drive). Pengaruh variasi komposisi flare gas terhadap MMP perlu dikaji lebih lanjut untuk menjajaki kelayakan injeksi flare gas dalam proses MGF-EOR.
\end{abstract}

Kata kunci: flare gas, MMP, miscible gas flooding, EOR

*corresponding author 


\section{Introduction}

Indonesia is a significant contributor to the global greenhouse gases (GHG) emissions caused by gas flaring in the oil and gas production sector. In this industrial sector, flare gases are hydrocarboncontaining byproducts from oil and gas surface production facilities that are regarded as waste streams due to its composition, uneconomical flow rate, and other reasons. These gases are typically incinerated in ground or marine flares. The contribution of gas flaring to $\mathrm{GHG}$ is associated primarily with the carbon dioxide emissions generated by the combustion of hydrocarbons in the gas. Incomplete combustion in the flare may also result in the emission of methane and other light hydrocarbons, which have even higher greenhouse effect than $\mathrm{CO}_{2}$.

In 2004, the total gas flaring rate in Indonesia was 358.3 MMSCFD, generated by 506 oil and gas production fields (Crosetti and Fuller, 2006). This is equivalent to approximately $4.3 \%$ of the total natural gas production rate in Indonesia. In 2002, GHG emission generated by gas flaring in Indonesia accounted for $72 \%$ of the total GHG emission in the Asia-Oceania region, or approximately $5.6 \%$ of the global emission (Indriani, 2005).

Aside from gas flaring, declining oil production is another looming problem facing the Indonesian oil and gas industry. The national oil production peaked in 1996, then steadily declined due to slow investment, decrease in new explorations to replace aging fields, and bureaucratic issues. Contribution of Indonesian crude oil production to the global crude oil production was $2.21 \%$ in 1990 , declining to $1.82 \%$ in 2001. The projected contribution in 2020 is $1.31 \%$ (Indriani, 2005).

The need to sustain or increase oil production from declining oilfields may be supported by various enhanced oil recovery (EOR) methods. One such method is the miscible gas flooding EOR (MGF-EOR), in which in injection gas is flooded from an aboveground source into the reservoir at a sufficiently high pressure to render it completely miscible with the crude oil. Above a certain threshold pressure, known as the minimum miscibility pressure (MMP), the interface between injection gas and crude oil trapped in the reservoir disappears. The gas- oil mixture becomes supercritical, hence greatly enhancing its mobility through the porous reservoir rocks and facilitating its recovery. Commonly used injection gases include $\mathrm{CO}_{2}$ and condensable hydrocarbons. To date, the use of flare gas in MGF-EOR has not been explored in detail. If such application is techno-economically feasible, then this method would represent a synergy between oil production improvement and GHG emissions reduction efforts.

This paper discusses the impact of using flare gas on the oil-gas miscibility development behavior in MGF-EOR process. It is generally known that the MMP is greatly influenced by the compositions of the trapped crude oil and the injection gas, and by the reservoir temperature. The development of miscibility at pressures above MMP may occur via two idealized mechanisms, namely the vaporizing gas drive mechanism (VGDM) and condensing gas drive mechanism (CGDM). In VGDM, intermediate hydrocarbon species evaporate from the oil to the sweeping lean injection gas, such that the composition of the gas approaches that of the oil. In CGDM, the intermediate hydrocarbons condense from the rich injection gas into the oil, shifting the oil composition towards that of the injection gas. Due to the role of MMP as a key design parameter in the development of MGF-EOR systems, it is of practical interest to compare the MMP values obtained by miscible flare gas injection to those in miscible $\mathrm{CO}_{2}$ (or conventional) gas injection.

The most widely used laboratory measurement method for MMP is the slim tube method, in which a long, small-diameter coiled tube packed with sand or glass beads is filled with crude oil and kept at a constant temperature. The injection gas is introduced at one end of the tube at a prescribed pressure and total volume. Oil displaced by the gas is collected at the other end of the tube, and the recovered oil versus pressure profile data are used to estimate the MMP. According to Yellig and Metcalfe (1980), slim tube method is generally capable of representing the interaction between flow of fluids in porous media and their phase behavior. However, to reduce viscous fingering and dispersion effects, relatively long, narrow tubes operated at very low fluid flow rates are typically preferred. Unfortunately, these design and operating 
parameters also mean that the test is very slow, requiring 4-5 weeks to determine the MMP of a particular system (Ayirala and Rao, 2007). Another drawback of the slim tube test is that there is no universally accepted standard method for determining MMP from the obtained raw data (El-sharkawy et al., 1996).

Other experimental methods for MMP measurement are available. In the rising bubble apparatus, MMP is determined based on visual observation of changes in the geometry of injection gas bubbles rising through a stagnant, thin column of crude oil (Mihcakan and Poettman, 1994). While this method is considerably faster than the slim tube test, it suffers from the subjectivity in interpreting the bubble geometry to determine the MMP. Another example is the MMP measurement by the vanishing interfacial tension method. In this method, the gas-oil interfacial tension is determined by measuring the capillary rise in a highpressure optical cell heated at the reservoir temperature. The interfacial tension measurement is done at several pressures, and the MMP is estimated by extrapolating to zero interfacial tension (Rao, 1997). Both the rising bubble and vanishing interfacial methods are not very accurate due to their inability to fully represent the interaction between flow and phase equilibrium behavior when the gas flooding involves a combination of condensing and vaporizing gas drives (Orr and Jessen, 2007).

These disadvantages of experiment methods for MMP determination have motivated the development of computational methods for estimating the MMP. Ahmadi and Johns (2008) classified the computational techniques proposed in the literature according to the following approaches: (1) 1-dimensional analytical calculations (2) 1-dimensional slim tube simulation (3) single or multiple mixing-cell method.

The analytical calculation approach is based on the analytical solution of 1dimensional flow equations described by Orr (2005). Several key findings have been reported by authors employing this computational approach. Orr et al. (1993) and Johns et al. (1993) described the existence of the 3 key tie lines in systems with more than 3 components, i.e. the initial, injection and crossover tie lines. These authors also described the MMP as the pressure at which any of these key tie lines becomes critical, i.e. its length approaches zero. Johns and Orr (1996) observed that the number of key tie lines controlling the miscibility development is $n_{c}-1$, where $n_{c}$ is the number of components in the system. These key tie lines consists of an injection tie line which intersects the injection gas composition, an initial tie line which intersects the crude oil composition, and $\mathrm{n}_{\mathrm{c}}-3$ crossover tie lines which connect the injection and initial tie lines.

The 1-dimensional slim tube simulation predicts the recovery of the oil in the slim tube experiment as a function of pressure using fine-grid compositional computation. Aside from being timeconsuming, such computation is also prone to errors due to numerical dispersion (Johns et al., 2002).

In the mixing cell approach, the gas and oil are mixed in repeated contacts (Metcalfe et al., 1973). Equilibrium vaporliquid compositions resulting from these contacts are determined by flash calculations, and are used to determine the key tie lines. The critical tie line in gas flooding by VGDM is the initial tie line. Conversely, when the gas flooding occurs via the CGDM, the critical tie line is the injection tie line. For systems with four or more components controlled by the combined vaporizing and condensing drive mechanism, the critical tie line is one of the $\mathrm{n}_{\mathrm{c}}-3$ crossover tie lines. Jaubert et al. (1998) described the multiple-mixing cell (MMC) model as strictly a series of equilibrium cells that disregard any fluid transport parameter (see Figure 1). These authors argued that MMP only depends on the phase equilibrium, and is not affected by variables associated with flow through porous media, such as relative permeability, capillary pressure, and interfacial tension. The MMC model is particularly promising due to its relative simplicity and computation robustness.

\section{Methodology}

The MMC model from Metcalfe et al. (1973) and Jaubert et al. (1998) is selected as the core computational model. The mixing cell number is constant, and the cell volumes are uniform. At the beginning of the computation, the cells are fully filled with the oil to be displaced. The injection gas is then introduced as discrete volumes to cell 


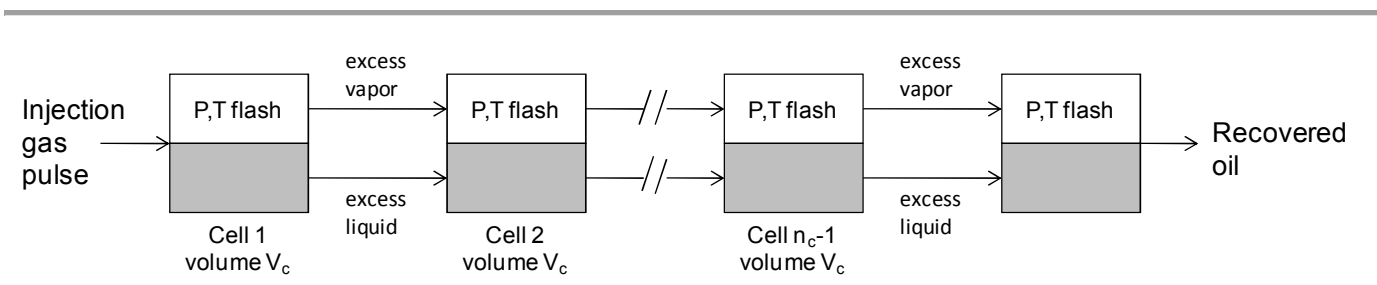

Figure 1. Multiple-mixing cell model (Samadhi et al., 2009)

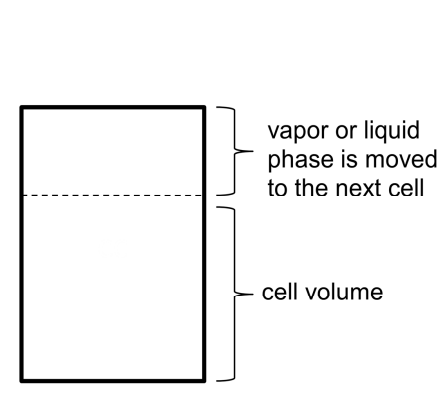

(a) Monophasic - the cell contains only vapor or liquid after flashing

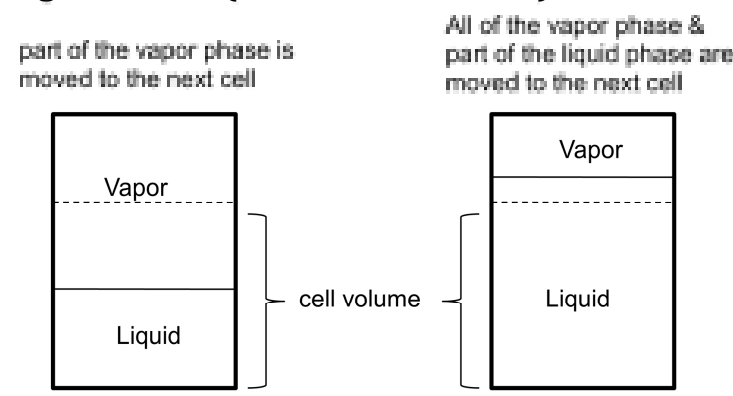

(a) Diphasic - the cell contains both vapor and liquid after flashing

Figure 2. Fluid partitioning rules in MMC calculation according to Jaubert et al. (1998)

number 1. A P,T-flash calculation is performed in cell number 1 . If the overall mixture lies in the two-phase envelope in the phase diagram, then the calculation produces the compositions of the vapor and liquid phases, and identifies the tie line of the particular cell. When the volume of the overall vapor-liquid mixture after flashing exceeds the cell volume, the fluid is partitioned to cell number 2 according to the following rules (Jaubert et al., 1998):

1. When the cell contains only vapor or liquid, move the fluid in excess of the cell volume to the next cell.

2. When the cell contains both vapor and liquid, the vapor phase takes the higher priority in the partitioning:

- Move the vapor in excess of the cell volume to the next cell.

- If the entire vapor phase has been moved and the volume of the remaining liquid is still in excess of the cell volume, then move the excess liquid to the next cell.

The above fluid partitioning rules are presented schematically in Figure 2.

The computational package is developed on the Fortran language platform, and was described in greater detail in an earlier work (Samadhi et al., 2009). Computation of the vapor and liquid equilibrium uses the Peng-Robinson equation of state. Published pure-component and binary interaction parameters $\left(\mathrm{k}_{\mathrm{ij}}\right)$ are used (Danesh, 1998). Variables set prior to the computation include cell number, cell volume, oil composition, injection gas composition, temperature, pressure, and gas to oil ratio (GOR), which refers to the molar ratio between the injection gas pulse and the oil initially placed in one cell.

A cell-to-cell sequential mixing, flashing, and partitioning calculation is performed for each injection gas pulse, defined as one calculation batch. Equilibrium vapor and liquid compositions are recorded, and are used to calculate the tie line length. Key tie lines are identified as constant tie line length vs. cell number zones. The batch-tobatch calculations are undertaken until all key tie lines are identified. The system pressure is then increased, and the calculation is started from the first injection gas pulse again. This computational process is carried out at increasing pressures, until the length of one of the key tie lines approaches zero.

Two systems are considered in the present work:

1. ternary $\mathrm{CO}_{2}-\mathrm{nC}_{5} \mathrm{H}_{12}-\mathrm{nC}_{16} \mathrm{H}_{34}$ system at $323.15 \mathrm{~K}$ representing the conventional $\mathrm{CO}_{2}$ flooding of crude oil, with a model oil composition of $43.0 \%$-mol n-pentane and $57.0 \%$-mol n-hexadecane

2. quaternary $\mathrm{CH}_{4}-\mathrm{C}_{2} \mathrm{H}_{6}-\mathrm{nC}_{5} \mathrm{H}_{12}-\mathrm{nC}_{16} \mathrm{H}_{34}$ system at $323.15 \mathrm{~K}$, representing the replacement of the $\mathrm{CO}_{2}$ in the previous 
case by a model flare gas with a composition of $91.0 \% \mathrm{CH}_{4}$ and $9.0 \% \mathrm{C}_{2} \mathrm{H}_{6}$

The selection of the n-pentane - nhexadecane model oil system and the temperature is based on the laboratory measurement work by Mihcakan and Poettman (1994) and Yang et al. (2007). The composition of the binary injection flare gas is normalized from the composition described by Crosetti and Fuller (2005) to represent typical Indonesian flare gas compositions in their work. This normalization is necessary, since the original composition described by the aforementioned authors contains more than two components. A previous work on the application of several equations of state in the MMP calculation of the ternary $\mathrm{CO}_{2}-\mathrm{n}$ pentane - n-hexadecane system in a purely predictive computational mode (Samadhi et al., 2009) has confirmed that the miscibility development of this system occurs via the VGDM.

In the current work, the MMP obtained by using flare gas injection is compared to that obtained using $\mathrm{CO}_{2}$. If the MMP is comparable, or even lower, then the flare gas injection is likely to be technically feasible as a replacement for $\mathrm{CO}_{2}$ in MGF-EOR processes. If the MMP in the flare gas injection case is substantially higher than the conventional $\mathrm{CO}_{2}$ injection case, then a further study is needed to identify conditions under which the flare gas injection may be feasible.

\section{Results and Discussion}

The raw data generated by the multiple-mixing cell calculations consist of the equilibrium vapor-liquid compositions, overall fluid mixture compositions, and tie line length over the entire chain of mixing cells. This data is generated in each injection gas pulse, or calculation batch.

As a snapshot example of this raw data for the flooding of the model n-pentane - nhexadecane oil by $\mathrm{CO}_{2}$, Figure 3 presents the tie line vs. cell number plot at one pressure value $(9.0 \mathrm{MPa})$ and one calculation batch (batch number 366). Constant tie line length zones in this type of plot are associated with the key tie lines. Therefore, two key tie lines are identified in Figure 3, namely the injection tie line at lower cell numbers and the initial tie line at higher cell numbers, in accordance to the $\mathrm{n}_{\mathrm{c}}-1$ number of key tie lines rule (Johns and Orr, 1996). A relatively gradual shift in tie line length occurs between the injection and initial tie lines. This is the phenomenon alluded to as the rarefaction by Orr et al. (1995).

As expected, the key tie lines become shorter as the system pressure is increased, as indicated in Figure 4. At pressures above 9.6 $\mathrm{MPa}$, the length of the initial tie line decreases much faster than the injection tie line. The calculation was terminated at 9.74 MPa due to convergence failures. The MMP is determined by extrapolating the strongly non-linear portion of the injection tie line length curve to zero value, producing an MMP estimate of 9.78 MPa. Compared to the laboratory measurement value of $10.55 \mathrm{MPa}$ (Yang et al., 2007), the value estimated using the MMC model is approximately 7.3\% lower. This underestimation of MMP is in contrary to the calculation results described by Firoozabadi and Aziz (1986) and Lee and Reitzel (1982) using 1-dimensional flow simulator and Peng-Robinson equation of state, who obtained MMP estimates that are consistently higher than the measured value for four different reservoir fluids. These authors attributed this discrepancy to the inaccuracy in critical point estimation due to lack of PVT data in the critical region to finetune the equation of state.

Since obtaining a high accuracy in MMP estimation is secondary to comparing the miscibility development behavior in $\mathrm{CO}_{2}$ and flare gas injection in the current work, binary interaction parameters readily available in the literature (Danesh, 1998) are used directly and are not re-optimized with respect to the phase behavior in the critical region. Therefore, an MMP estimate error of $7.3 \%$ is still deemed acceptable. As a comparison, Jaubert et al. (2002) observed an average deviation of $7.6 \%$ between calculated MMP values and those measured by the slim tube method for 13 crude oil samples.

When the flare gas replaces $\mathrm{CO}_{2}$ as the injection gas, the system becomes quaternary. Figure 5 presents an example of the tie line length vs. cell number for the flare gas injection MMC calculation at $323.15 \mathrm{~K}$, the same temperature as the previous case. This particular raw data snapshot was captured at a pressure of $34.0 \mathrm{MPa}$ and batch number 2400. Three constant tie line length zones are identified, associated with the 


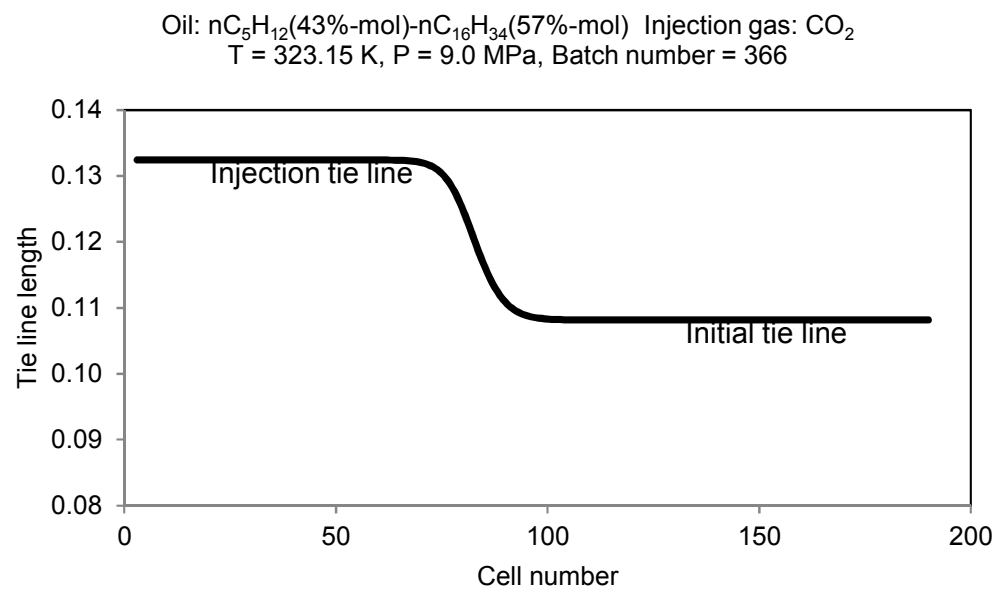

Figure 3. Example of tie line length vs. cell number calculation result for the injection of the model oil (n-pentane:n-hexadecane $=43: 57 \%$-mol) by pure $\mathrm{CO}_{2}$ at 323.15 $\mathrm{K}$ and 9.0 MPa, taken at batch number 366

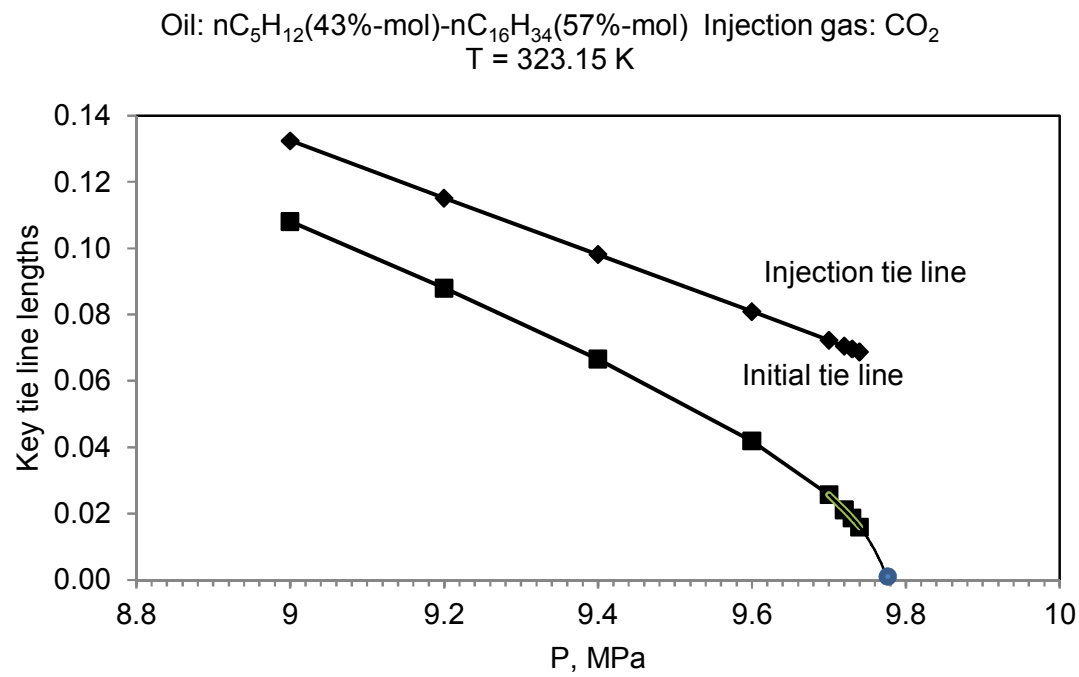

Figure 4. Key tie line lengths at varying pressure for the injection of the model oil (n-pentane:n-hexadecane $=43: 57 \%$-mol) by pure $\mathrm{CO}_{2}$ at 323.15 K (MMP = 9.78 MPa)

injection, crossover, and initial tie lines, respectively. The injection and crossover tie lines are connected by a transition region in which the tie line length changes rapidly. This abrupt change is defined as a 'shock' according to Orr et al. (1995). The crossover and initial tie lines are connected by a rarefaction.

Two striking differences between the flare gas and $\mathrm{CO}_{2}$ injection may be readily observed. The shortest tie line (which becomes the critical tie line as the system pressure approaches the MMP) is now the crossover tie line. This suggests that the miscibility development mechanism shifts from VGDM to a combined vaporizing / condensing drive mechanism (Orr et al., 1995). Another difference is the much higher miscibility development pressure compared to the $\mathrm{CO}_{2}$ injection case. At a pressure of $34.0 \mathrm{MPa}$, which is already almost 3.5 times the MMP of the $\mathrm{CO}_{2}$ injection case, the length of the shortest tie line is still in the vicinity of 0.1 .

Figure 6 plots the key tie line lengths against system pressure for the flare gas injection to the model n-pentane - nhexadecane oil. The MMP value, estimated by 
Oil: $\mathrm{nC}_{5} \mathrm{H}_{12}(43 \%-m o l)-\mathrm{nC}_{16} \mathrm{H}_{34}(57 \%-m o l)$ Injection gas: $\mathrm{CH}_{4}(91 \%$ $\mathrm{mol})-\mathrm{C}_{2} \mathrm{H}_{6}(9 \%$-mol $)$

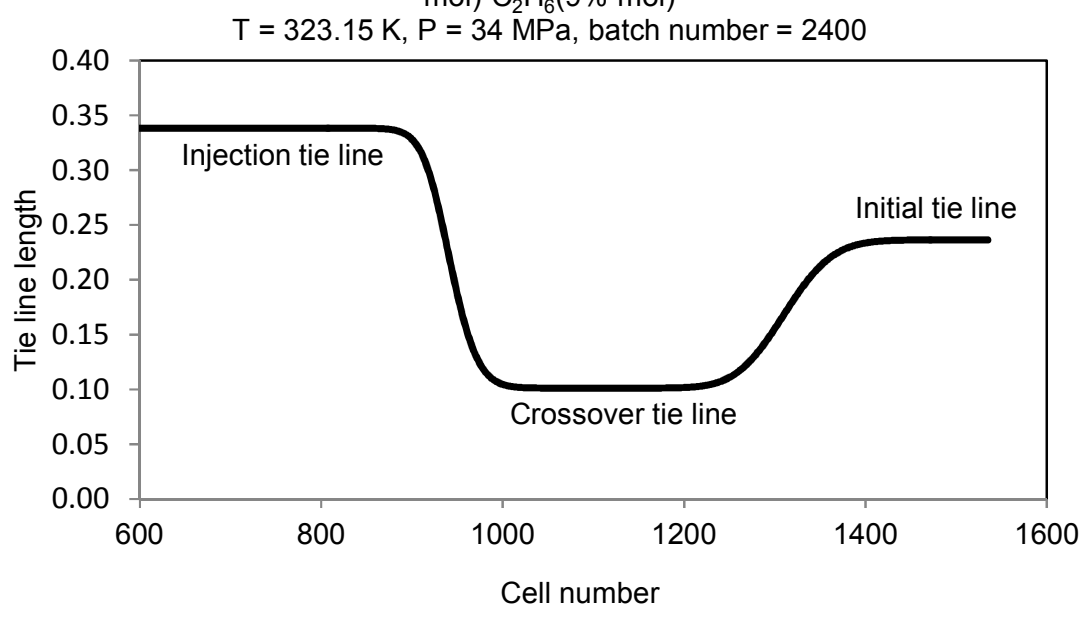

Figure 5. Example of tie line length vs. cell number calculation result for the injection of the model oil (n-pentane:n-hexadecane $=43: 57 \%$-mol) by model flare gas (methane:ethane $=91: 9 \%-\mathrm{mol}$ ) at 323.15 $\mathrm{K}$ and 34.0 $\mathrm{MPa}$.
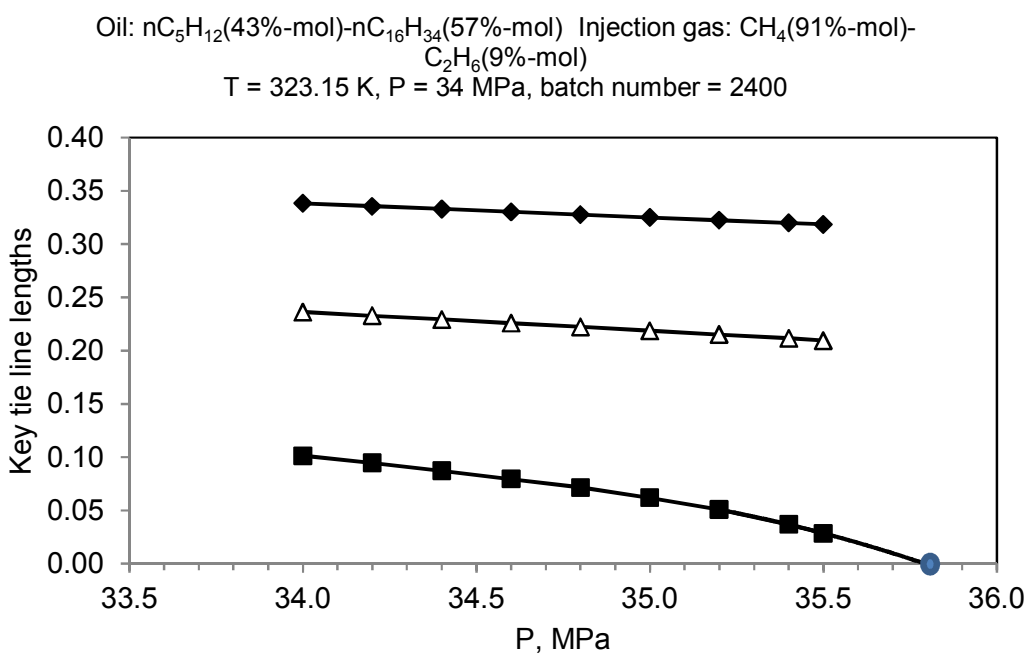

Figure 6. Key tie line lengths at varying pressure for the injection of the model oil

(n-pentane:n-hexadecane $=43: 57 \%$-mol) by model flare gas

(methane:ethane $=91: 9 \%-\mathrm{mol})$ at 323.15 K (MMP = 95.8 MPa)

extrapolation analogous to the $\mathrm{CO}_{2}$ injection case, is $35.8 \mathrm{MPa}$. This value is 3.66 times the estimated MMP of the $\mathrm{CO}_{2}$ injection, or approximately 3.39 times the measured MMP value (Yang et al., 2007).

The very large increase in MMP when flare replaces $\mathrm{CO}_{2}$ as the injection gas is likely to be due to the much higher critical pressure of methane. Figure 6 also indicates that the decrease in the crossover tie line length at pressures near the MMP is not as rapid as the decrease observed in the $\mathrm{CO}_{2}$ injection case (compare to Figure 5). While not directly addressed in the current work, the miscibility between the injection flare gas and the oil may also be approached by increasing the ethane content of the flare gas at a constant pressure. At a certain ethane 'enrichment' level, the crossover tie line would become critical. The concentration of the intermediate-component (in this case ethane) at which this criticality is obtained is known as the minimum miscibility enrichment or MME (Orr et al., 1995). 
The extremely high MMP predicted for the flare gas injection presents a number of challenges for the future work. The GHG emission reduction potential of the flare gas injection needs to be weighed against the investment and operating costs of gas compression and delivery system, and the maximum pressure that the reservoir rock structure itself can withstand. Other alternatives should also be explored, including the enrichment of the flare gas with intermediate hydrocarbons, the use of flare gas - $\mathrm{CO}_{2}$ mixture as the injection gas (e.g. by partial combustion of the flare gas), or even the utilization of dehydrated postcombustion flue gas from flares as an injection gas.

\section{Conclusions}

The calculation of minimum miscibility pressure in the simulated flooding of a model oil consisting of n-pentane and nhexadecane at near-equimolar proportions by $\mathrm{CO}_{2}$ gas using the multiple mixing cell method yields a reasonably accurate result, in which the calculated MMP is $7.3 \%$ lower than the published laboratory measurement data.

The use of a model flare gas comprising of $91 \%$-mol methane and balance ethane in the flooding of the above oil is predicted to increase the MMP by 3.66 times compared to $\mathrm{CO}_{2}$ injection.

The extremely large increase in the MMP when flare gas is used as the injection gas is likely to be due to the much higher critical pressure of methane compared to $\mathrm{CO}_{2}$, and is likely to render the MGF-EOR process by flare gas injection uneconomical as it is.

Further studies exploring other means of utilizing using flare gas in EOR processes may include the injection of flare gas $-\mathrm{CO}_{2}$ mixture and study of the effect of increasing intermediate hydrocarbon components in the injection gas.

\section{Acknowledgments}

The author thanks the Center for Research and Community Empowerment at Institut Teknologi Bandung (LPPM-ITB) for their financial support of this research through the 2011 ITB Innovation and Expertise Groups Research (Riset Inovasi dan Kelompok Keahlian ITB 2011). Special thanks are given to Dr. Hertanto Adidharma and Dr. Sugata Tan at the University of Wyoming, whose subroutines form the basis in constructing the current MMC computational package.

\section{References}

Ahmadi, K.; Johns, R. T. Multiple mixing-cell method for MMP calculations, SPE 116823, 2008. SPE Annual Technical Conference and Exhibition, Denver, Colorado, USA, September 21-24, 2008; 1-10.

Ayirala, S. C.; Rao, D. N. Miscibility determination from gas-oil interfacial tension and P-R equation of state. The Canadian Journal of Chemical Engineering. 2007, 85(3), 302-312.

Crosetti, M.; Fuller, D. Indonesia Associated Gas Survey - Screening and Economic Analysis Report, The World Bank / GGFR, Jakarta, Indonesia, 2006, 2.4-2.6, 4.4.

Danesh, A. PVT and Phase Behavior of Petroleum Reservoir Fluids; Elsevier Science BV: Amsterdam, Netherlands, 1998; 354-355, 360 .

El-sharkawy, A. M.; Poettman, F. H.; Christiansen, R. L. Measuring $\mathrm{CO}_{2}$ minimum miscibility pressure: slim-tube of rising bubble method. Energy and Fuels. 1996, 10 (2), 443-449.

Firoozabadi, A.; Aziz, K. Analysis and correlation of nitrogen and lean gas miscibility pressure. SPE Reservoir Engineering Journal. 1986, 1(6), 575-582.

Indriani, G. Gas Flaring Reduction in the Indonesian Oil and Gas Sector: Technical and Economic Potential of Clean Development Mechanism (CDM) Projects, Hamburg Institute of International Economics, Hamburg, Germany, 2005, 46-53.

Jaubert, J. N.; Wolff, L.; Neau, E.; Avaullee, L. A very simple multiple mixing cell calculation 
to compute the minimum miscibility pressure whatever the displacement mechanism. Industrial and Engineering Chemistry Research. 1998, 37(12), 48544859.

Jaubert, J. N.; Avaullee, C.; Pierre, C. Is it still necessary to measure the minimum miscibility pressure. Industrial and Engineering Chemistry Research. 2002, 41(2), 303-310.

Johns, R. T.; Dindoruk, B.; Orr, F. M. Analytical Theory of Combined Condensing/Vaporizing Gas Drive. SPE Advanced Technology Series. 1993, 1(2), 7-16.

Johns, R. T.; Orr, F. M. Miscible gas displacement of multicomponent oils. SPE Journal. 1996, 1(1), 39-50.

Johns, R. T.; Sah, P.; Solano, R. Effect of dispersion on local displacement efficiency for multicomponent enriched-gas floods above the minimum miscibility enrichment. SPE Reservoir Engineering. 2002, 5(1), 4-10.

Lee, J. I.; Reitzel, G. A. High pressure, dry gas miscible flood - brazeau river nisku oil pools. Journal of Petroleum Technology. 1982, 34(11), 2503-2509.

Metcalfe, R. S.; Fussell, D. D.; Shelton, J. L. A multicell equilibrium separation model for the study of multiple contact miscibility in rich-gas drives. SPE Journal. 1973, 13(3), 147-155.

Mihcakan, M.; Poettmann, F. H. Minimum Miscibility Pressure, Rising Bubble Apparatus and Phase Behavior, SPE 27815, 1994. SPE/DOE Symposium on Improved Oil Recovery, Tulsa, Oklahoma, USA, April 17-20, 1994; 361-369.
Orr, F. M.; Dindoruk, B.; Johns, R. T. Theory of multicomponent gas/oil displacements. Industrial and Engineering Chemistry Research. 1995, 34(8), 2661-2669.

Orr, F. M.; Jessen, K. An Analysis of the Vanishing Interfacial Tension Technique for Determination of Minimum Miscibility Pressure. Fluid Phase Equilibria. 2007, 255(2), 99-109.

Orr, F. M.; Johns, R. T.; Dindoruk, B. Development of miscibility in fourcomponent $\mathrm{CO}_{2}$ floods. SPE Reservoir Engineering Journal. 1993, 8(2), 135-142.

Orr, F. M. Theory of Gas Injection Processes, Stanford University, Menlo Park, California, USA, 2005; 5-15.

Rao, D. N. A new technique of vanishing interfacial tension for miscibility determination. Fluid Phase Equilibrium. 1997, 139(1-2), 311-324.

Samadhi, T. W.; Adidharma, H.; Tan, S. P. Purely Predictive Application of Statistical Associating Fluid Theory for Enhanced Oil Recovery by Miscible Gas Flooding. Proceedings of the 2009 Regional Symposium on Chemical Engineering, Santo Tomas University, Manila, Philippines, 1-2 December, 2009.

Yang, F.; Zhao, G. B.; Adidharma, H.; Towler, B.; Radosz, M. Effect of oxygen on minimum miscibility pressure in carbon dioxide flooding. Industrial and Engineering Chemistry Research. 2007, 46(4), 1396-1401.

Yellig, W. F.; Metcalfe, R. S. Determination of $\mathrm{CO}_{2}$ minimum miscibility pressure. Journal of Petroleum Technology. 1980, 32(1); 160-168. 